\title{
Reassessment of the systematics of the suborder Pseudonocardineae: transfer of the genera within the family Actinosynnemataceae Labeda and Kroppenstedt 2000 emend. Zhi et al. 2009 into an emended family Pseudonocardiaceae Embley et al. 1989 emend. Zhi et al. 2009
}

Correspondence

D. P. Labeda

David.Labeda@ars.usda.gov
D. P. Labeda, ${ }^{1}$ M. Goodfellow, ${ }^{2}$ J. Chun, ${ }^{3}$ X.-Y. Zhii ${ }^{4}$ and W.-J. Li ${ }^{4}$

\author{
${ }^{1}$ National Center for Agricultural Utilization Research, USDA-ARS, Peoria, IL 61604, USA \\ ${ }^{2}$ School of Biology, University of Newcastle, Newcastle upon Tyne NE1 7RU, UK \\ ${ }^{3}$ School of Biological Sciences, Seoul National University, Shillim-dong, Kwanak-gu, \\ Seoul 151-742, Republic of Korea \\ ${ }^{4}$ The Key Laboratory for Microbial Resources of the Ministry of Education and Laboratory for \\ Conservation and Utilization of Bio-Resources, Yunnan Institute of Microbiology, \\ Yunnan University, Kunming 650091, PR China
}

The suborder Pseudonocardineae as proposed by Stackebrandt et al. (1997) contained only a single family, the Pseudonocardiaceae Embley et al. 1989. Subsequently, Labeda \& Kroppenstedt (2000) proposed that, on the basis of phylogenetic analysis of 16S rRNA gene sequences for a subset of all taxa within the family, the genera Actinosynnema, Actinokineospora, Lentzea and Saccharothrix should be placed in the new family Actinosynnemataceae. The description of the family Actinosynnemataceae was recently emended by Zhi et al. (2009) to include member

A supplementary table is available with the online version of this paper. genera described since 2000, namely Lechevalieria Labeda et al. 2001 and Umezawaea Labeda and Kroppenstedt 2007.

The taxonomic status of the families Actinosynnemataceae and Pseudonocardiaceae was assessed in the present study on the basis of phylogenetic analysis of 151 currently available 16S rRNA gene sequences and previously described chemotaxonomic and morphological properties of the member genera and species. It was observed that there is inadequate phylogenetic or chemotaxonomic support to maintain the family Actinosynnemataceae, as currently delineated, and it is proposed that the taxa within this family be transferred to the family Pseudonocardiaceae, 
whose description is emended to accommodate these genera.

The 16S rRNA gene sequences for the type strains of all taxa within the suborder Pseudonocardineae were obtained from the SILVA database maintained at the Technical University of Munich (http://www.arb-silva.de/) or from locally maintained alignments, and subjected to phylogenetic analyses using ARB (Ludwig et al., 2004). The list of taxa, their strain numbers and the accession numbers of their 16S rRNA gene sequences in the public databases can be found in Supplementary Table S1, available in IJSEM Online. The alignment was trimmed at both ends to include only positions that contained data for all strains, totalling 1276 bases. The 16S rRNA gene sequence of Micrococcus luteus DSM $20030^{\mathrm{T}}$ was used as the outgroup for analyses. This dataset was also subsequently evaluated using jPhydit (Jeon et al., 2005) to filter out the hypervariable loop regions from the analyses in order to determine the phylogenetic impact of these regions (not shown).

Phylogenetic analyses of $16 \mathrm{~S}$ rRNA gene sequence data for all taxa currently described within the suborder Pseudonocardineae do not support the current description of the family Actinosynnemataceae, as can be seen in Fig. 1 .
The species of the genus Actinokineospora are the most distant members of the clade that contains the other genera currently described within the family, namely Actinosynnema, Lechevalieria, Lentzea, Saccharothrix and Umezawaea, but this clade also contains the genera Actinoalloteichus, Alloactinosynnema, Allokutzneria, Crossiella, Goodfellowiella, Kutzneria and Streptoalloteichus. From a cursory examination of this phylogenetic tree, one can easily conclude that the suborder could be divided into three or more families rather than the current two, but these observations do not have statistical support in the present dataset, nor can signature nucleotide patterns be found that support any subdivision. Evaluation of the phylogeny of the $16 \mathrm{~S}$ rRNA gene sequence alignment with all hypervariable loop regions removed (not shown) also did not demonstrate phylogenetic support for subdivision of the suborder into more than one family.

An evaluation of the previously reported chemotaxonomic properties of the genera within the suborder Pseudonocardineae (Table 1) demonstrates that certain properties, such as the presence of meso-diaminopimelic acid and galactose in whole-cell hydrolysates and, generally, the presence of tetrahydrogenated menaquinones with nine

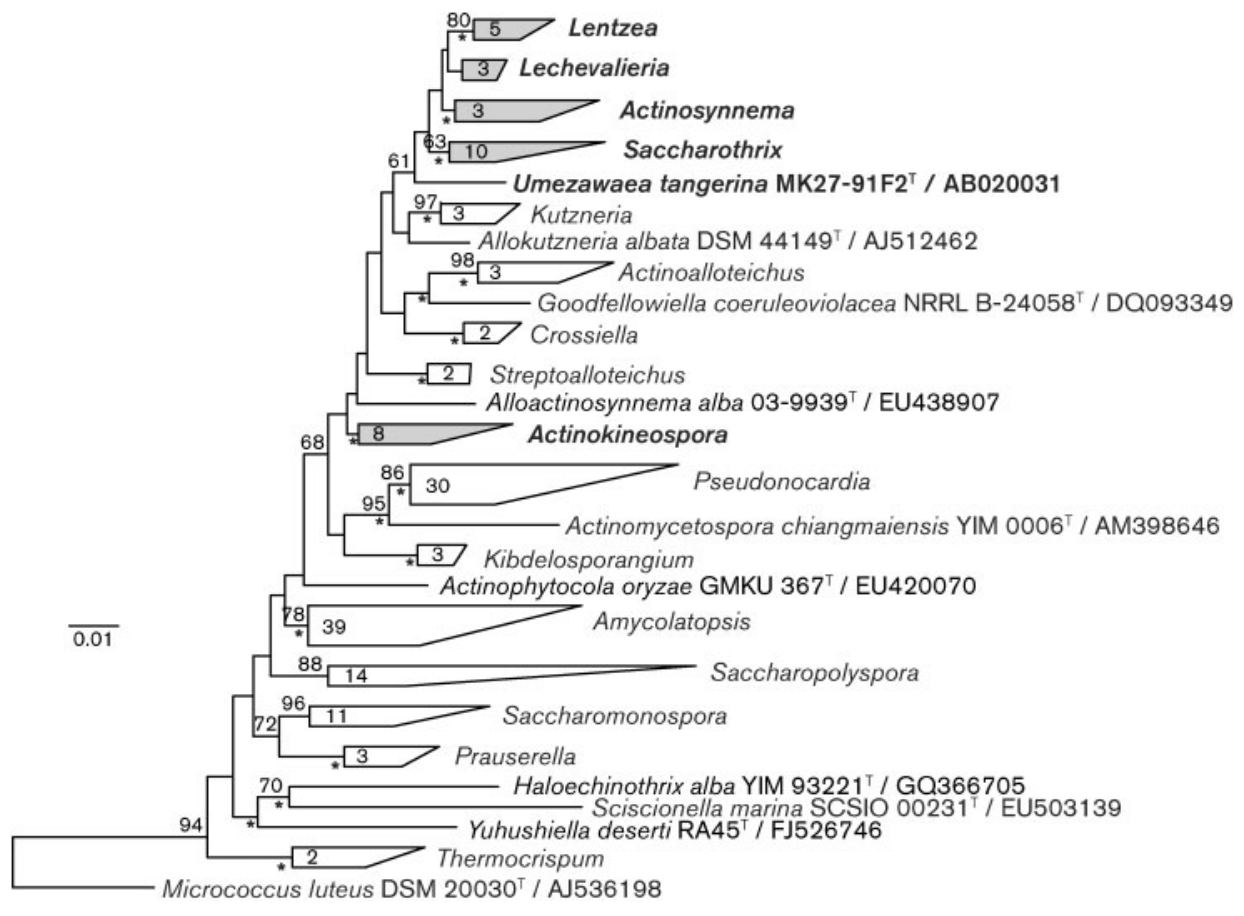

Fig. 1. Phylogenetic tree for the genera of the suborder Pseudonocardineae calculated from almost-complete 16S rRNA gene sequences (1276 nt) using Kimura's evolutionary-distance method (Kimura, 1980) and the neighbour-joining algorithm of Saitou \& Nei (1987). Percentages at nodes represent levels of bootstrap support from 1000 resampled datasets; values less than $60 \%$ are not shown. Numbers within each clustered group indicate the total number of taxa with validly published names included in the phylogenetic analyses that made up each cluster. The taxa, strain numbers and accession numbers of $16 \mathrm{~S}$ rRNA gene sequences can be found in Supplementary Table S1. Branches also conserved in maximum-parsimony (Felsenstein, 1989) and maximum-likelihood (Stamatakis et al., 2002) trees are marked with asterisks. Genera currently defined as members of the family Actinosynnemataceae are identified in bold. Bar, 0.01 substitutions per nucleotide site. 
repeating units [i.e. MK-9 $\left(\mathrm{H}_{4}\right)$ ], are common to all, but there is no observed segregation of properties that supports subdivision of the suborder into more than one family. For instance, the presence of arabinose in whole-cell hydrolysates is observed within genera scattered over the phylogenetic tree, such as Actinokineospora, Actinophytocola, Actinomycetospora, Allokutzneria, Amycolatopsis, Kibdelosporangium, Prauserella, Pseudonocardia, Saccharomonospora, Saccharopolyspora, Sciscionella, Thermocrispum and Yuhushiella, and therefore cannot be used to differentiate between members of the major clades within the suborder. Morphological properties, such as production of sporangia and motile spores, are also distributed throughout the taxa shown in Fig. 1, so they are of little differential use in grouping the genera into separate families.

In light of the lack of phylogenetic, chemotaxonomic and morphological support for differentiation of the genera within the family Actinosynnemataceae from those in the family Pseudonocardiaceae, as well as a lack of any strong support for any other subdivision of the suborder Pseudonocardineae at this time, it would appear that these genera should be transferred from the family Actinosynnemataceae into an emended family Pseudonocardiaceae. With the discovery, description and sequencing of many new taxa within the suborder Pseudonocardineae in the future, it might be possible to propose subdivision into additional families at a later date.

Formal emended descriptions of the family Pseudonocardiaceae and suborder Pseudonocardineae follow.

\section{Emended description of the family Pseudonocardiaceae Embley et al. 1989 emend. Zhi et al. 2009}

Pseudonocardiaceae (Pseu.do.no.car'di.ac.e.ae. N.L. fem. n. Pseudonocardia the type genus of the family; L. suff. -aceae ending to denote a family; N.L. fem. pl. n. Pseudonocardiaceae the Pseudonocardia family).

The family contains the type genus Pseudonocardia Henssen 1957 (Approved Lists 1980) emend. Park et al. 2008, as well as the genera Actinoalloteichus Tamura et al. 2000, Actinokineospora Hasegawa 1988b emend. Labeda et al. 2010 (effective publication Hasegawa, 1988a), Actinomycetospora Jiang et al. 2008, Actinophytocola Indananda et al. 2010, Actinosynnema Hasegawa et al. 1978, Alloactinosynnema Yuan et al. 2010, Allokutzneria Labeda and Kroppenstedt 2008, Amycolatopsis Lechevalier et al. 1986 emend. Lee 2009, Crossiella Labeda 2001, Goodfellowiella Labeda et al. 2008 (previous illegitimate name Goodfellowia Labeda and Kroppenstedt 2006), Haloechinothrix Tang et al. 2010, Kibdelosporangium Shearer et al. 1986, Kutzneria Stackebrandt et al. 1994, Lechevalieria Labeda et al. 2001, Lentzea Yassin et al. 1995 emend. Labeda et al. 2001, Prauserella Kim and Goodfellow 1999 emend. Li et al. 2003, Saccharomonospora Nonomura and Ohara 1971 (Approved Lists 1980), Saccharopolyspora
Lacey and Goodfellow 1975 (Approved Lists 1980) emend. Korn-Wendisch et al. 1989, Saccharothrix Labeda et al. 1984 emend. Labeda and Lechevalier 1989, Sciscionella Tian et al. 2009, Streptoalloteichus Tomita et al. 1987 emend. Tamura et al. 2008, Thermocrispum Korn-Wendisch et al. 1995, Umezawaea Labeda and Kroppenstedt 2007 and Yuhushiella Mao et al. 2011.

Aerobic, mesophilic or thermophilic, catalase-positive actinomycetes. Gram-positive. Not acid-fast. Morphologically heterogeneous; single or short chains of spores may be present on both aerial mycelium and substrate mycelium. Vegetative mycelium branches, diameter approximately $0.5-0.7 \mu \mathrm{m}$; aerial mycelium is produced and fragments in some genera into single smooth-surfaced, rod-shaped elements or chains of such elements. Some taxa may fail to produce aerial mycelium. Marked fragmentation of hyphae occurs in some taxa, but is absent in others. Other structures such as synnemata or dome-like bodies, sporangia or pseudosporangia may be produced in some genera. Motile spores may be produced in some genera. Most taxa are chemo-organotrophic, although some are autotrophic. A few taxa are halophilic. All genera contain meso-diaminopimelic acid as the diamino acid in their peptidoglycan and all except Haloechinothrix contain galactose as one of many diagnostic whole-cell sugars. Mycolic acids are not present in any of the genera. Tetrahydrogenated menaquinones of nine isoprene units are characteristic components, although menaquinones containing eight isoprene units predominate in the genus Pseudonocardia. The phospholipid profile generally includes phosphatidylethanolamine, sometimes containing hydroxylated fatty acids, as a major constituent, although representatives of one or more genera may also contain phosphatidylcholine. Resistant to lysozyme. The $\mathrm{G}+\mathrm{C}$ content of the DNA ranges from 66 to $74 \mathrm{~mol} \%$. The pattern of 16S rRNA signatures consists of nucleotides at positions 127:234 (G-C), $564(\mathrm{U}), 672: 734$ (U-G), $831: 855$ (U-G), 832:854 (G-Y), 833:853 (U-G), $952: 1229(\mathrm{U}-\mathrm{A})$ and $986: 1219(\mathrm{U}-\mathrm{A})$. Members of the family are found in a variety of environments, including soils, plant material, manure and clinical or veterinary samples. The type genus is Pseudonocardia Henssen 1957 (Approved Lists 1980) emend. Park et al. 2008.

\section{Emended description of the suborder Pseudonocardineae Stackebrandt et al. 1997 emend. Zhi et al. 2009}

Pseudonocardineae (Pseu.do.no.car'di.ne.ae. N.L. fem. n. Pseudonocardia the type genus of the suborder; N.L. suff. -ineae ending to denote a suborder; N.L. fem. pl. n. Pseudonocardineae the Pseudonocardia suborder).

Aerobic, mesophilic or thermophilic, catalase-positive actinomycetes comprising the family Pseudonocardiaceae, including the former members of the family Actinosynnemataceae. Morphology, chemotaxonomy, phylogeny and $16 \mathrm{~S}$ rRNA signature nucleotides are those of the 
Table 1. Comparison of chemotaxonomic profiles of genera within the order Pseudonocardineae

Data were obtained from the original and emended descriptions listed in the emended description of the family Pseudonocardiaceae.

\begin{tabular}{|c|c|c|c|c|c|c|}
\hline Genus & $\begin{array}{l}\text { Sporangia } \\
\text { produced }\end{array}$ & $\begin{array}{l}\text { Motile } \\
\text { spores }\end{array}$ & Whole-cell sugars ${ }^{\star}$ & Phospholipids $\dagger$ & $\begin{array}{c}\text { Predominant } \\
\text { menaquinone(s) }\end{array}$ & $\begin{array}{c}\text { DNA G+C } \\
\text { content } \\
(\mathrm{mol} \%)\end{array}$ \\
\hline Actinoalloteichus & None & No & Glc, Gal, Man, Rib & $\begin{array}{l}\text { PE, PIM, PI, PG, } \\
\text { DPG, PME }\end{array}$ & $9\left(\mathrm{H}_{4}\right)$ & $72-72.5$ \\
\hline Actinokineospora & None & Variable & Gal, Ara, Rha, Man & PE, DPG, PI & $9\left(\mathrm{H}_{4}\right)$ & 72.0 \\
\hline Actinomycetospora & None & No & Ara, Gal & PC, PI, PG & $9\left(\mathrm{H}_{4}\right)$ & 69.0 \\
\hline Actinophytocola & None & No & $\begin{array}{l}\text { Ara, Gal, Man, Rha, } \\
\text { Rib }\end{array}$ & PE, OH-PE & $9\left(\mathrm{H}_{4}\right)$ & 71.1 \\
\hline Actinosynnema & Synnemata & Yes & Gal, Man & $\begin{array}{l}\text { PE, OH-PE, } \\
\text { DPG }\end{array}$ & $\begin{array}{l}9\left(\mathrm{H}_{4}\right), \text { some } \\
9\left(\mathrm{H}_{6}\right)\end{array}$ & 73.0 \\
\hline Alloactinosynnema & Pseudosporangia & No & Gal, Rib & DPG, PG, PC & $9\left(\mathrm{H}_{4}\right)$ & 68.2 \\
\hline Allokutzneria & Yes; no spores & No & Ara, Gal, Man & $\begin{array}{l}\text { PE, PME, OH-PE, } \\
\text { PI, lyso-PME, DPG, } \\
\text { PG, lyso-PE }\end{array}$ & $9\left(\mathrm{H}_{4}\right)$ & 71.6 \\
\hline Amycolatopsis & None & No & Ara, Gal & PE, DPG, PG, PI & $9\left(\mathrm{H}_{4}\right)$ & $66.0-69.0$ \\
\hline Crossiella & None & No & Gal, Man, Rha, Rib & PE, PME, PI, PIM & $9\left(\mathrm{H}_{4}\right)$ & 74.1 \\
\hline Goodfellowiella & None & No & Gal, Rib & $\begin{array}{l}\text { PE, DPG, OH-PE, } \\
\text { PME }\end{array}$ & $9\left(\mathrm{H}_{4}\right), 10\left(\mathrm{H}_{4}\right)$ & 69.2 \\
\hline Haloechinothrix & None & No & Glc, Man, GlcN, NK & $\begin{array}{l}\text { DPG, PG, PE, PI, } \\
\text { PIM, PL }\end{array}$ & $8\left(\mathrm{H}_{4}\right)$ & 68.1 \\
\hline Kibdelosporangium & Yes & No & $\begin{array}{l}\text { Ara, Gal, Mad (v), } \\
\text { Glc (v), Rha (v) }\end{array}$ & $\begin{array}{l}\text { PE, PI, PME, PG, } \\
\text { DPG, PIM }\end{array}$ & $\begin{array}{l}9\left(\mathrm{H}_{4}\right), 9\left(\mathrm{H}_{6}\right) \\
9\left(\mathrm{H}_{10}\right)\end{array}$ & 66 \\
\hline Kutzneria & Yes & No & Gal, Rha & $\begin{array}{l}\text { PE, DPG, PI, PG, } \\
\text { PME }\end{array}$ & $9\left(\mathrm{H}_{4}\right)$ & $70.3-70.7$ \\
\hline Lechevalieria & None & No & Gal, Man, Rha (tr) & PE, DPG, PG, PI & $9\left(\mathrm{H}_{4}\right)$ & $68.0-71.4$ \\
\hline Lentzea & None & No & Gal, Man, Rib & PE, DPG, PI & $9\left(\mathrm{H}_{4}\right)$ & 71.4 \\
\hline Prauserella & None & No & Ara, Gal & DPG, PE & $9\left(\mathrm{H}_{2}\right), 9\left(\mathrm{H}_{4}\right)$ & $67-68.9$ \\
\hline Pseudonocardia & None & No & Ara, Gal & $\begin{array}{l}\text { PC, PE, PME, PI, } \\
\text { PIM, OH-PE }\end{array}$ & $8\left(\mathrm{H}_{4}\right)$ & $68-69$ \\
\hline Saccharomonospora & None & No & Ara, Gal & PE, DPG, PG, PI & $9\left(\mathrm{H}_{4}\right)$ & $66.0-70.0$ \\
\hline Saccharopolyspora & None & No & Ara, Gal & $\begin{array}{l}\text { PC, PE, DPG, } \\
\text { PG, PI }\end{array}$ & $9\left(\mathrm{H}_{4}\right)$ & $66.0-74.0$ \\
\hline Saccharothrix & None & No & Gal, Rha, Man (tr) & $\begin{array}{l}\text { PE, OH-PE, DPG, } \\
\text { PG, PI, PIM }\end{array}$ & $9\left(\mathrm{H}_{4}\right), 10\left(\mathrm{H}_{4}\right)$ & 71.4 \\
\hline Sciscionella & None & No & Ara, Gal, Glc & $\begin{array}{l}\text { DPG, PC, PE, PI, } \\
\text { PL, PME }\end{array}$ & $9\left(\mathrm{H}_{4}\right)$ & 69.0 \\
\hline Streptoalloteichus & Pseudosporangia & Variable & Gal, Man, Rha & $\begin{array}{l}\text { PE, DPG, PI, PIM, } \\
\text { PME }\end{array}$ & $9\left(\mathrm{H}_{6}\right), 10\left(\mathrm{H}_{6}\right)$ & 71.6 \\
\hline Thermocrispum & Pseudosporangia & No & $\begin{array}{l}\text { Ara, Man, Glc, } \\
\text { Gal (tr) }\end{array}$ & PE, PI, OH-PE & $9\left(\mathrm{H}_{4}\right)$ & $69.0-73.0$ \\
\hline Umezawaea & None & No & $\begin{array}{l}\text { Gal, Man, Rib, Rha } \\
\text { (tr) }\end{array}$ & $\begin{array}{l}\text { PE, PI, OH-PE, } \\
\text { lyso-PE }\end{array}$ & $9\left(\mathrm{H}_{4}\right), 10\left(\mathrm{H}_{4}\right)$ & 74.0 \\
\hline Yuhushiella & Pseudosporangia & No & $\begin{array}{l}\text { Ara, Gal, Glc, } \\
\text { Rib }\end{array}$ & $\begin{array}{l}\text { PE, PIM, PME, } \\
\text { DPG, PL, GlcNu }\end{array}$ & $9\left(\mathrm{H}_{4}\right)$ & 69.9 \\
\hline
\end{tabular}

${ }^{\star}$ Ara, Arabinose; Gal, galactose; Glc, glucose, GlcN, glucosamine; Mad, madurose; Man, mannose; Rha, rhamnose; Rib, ribose; NK, unknown sugar; tr, trace; $\mathrm{v}$, sugar is variably present in whole-cell hydrolysates.

$\nmid$ DPG, Diphosphatidylglycerol; GlcNu, phospholipids of unknown structure containing glucosamine; OH-PE, phosphatidylethanolamine with hydroxy fatty acids; lyso-PE, phosphatidylethanolamine where one fatty acid chain is missing from the glycerol backbone; lyso-PME, phosphatidylmethylethanolamine where one fatty acid chain is missing from the glycerol backbone; PC, phosphatidylcholine; PE, phosphatidylethanolamine; PG, phosphatidylglycerol; PI, phosphatidylinositol; PIM, phosphatidylinositol mannosides; PL, unknown phospholipids; PME, phosphatidylmethylethanolamine. 
family Pseudonocardiaceae. The type genus is Pseudonocardia Henssen 1957 (Approved Lists 1980) emend. Park et al. 2008.

\section{Acknowledgements}

Names are necessary to report factually on available data; however, the USDA neither guarantees nor warrants the standard of the product, and the use of the name by USDA implies no approval of the product to the exclusion of others that may also be suitable.

\section{References}

Embley, M. T., Smida, J. \& Stackebrandt, E. (1989). Pseudonocardiaceae fam. nov. In Validation of the Publication of New Names and New Combinations Previously Effectively Published Outside the IJSB, List no. 29. Int J Syst Bacteriol 39, 205-206.

Felsenstein, J. (1989). PHYLIP (phylogeny inference package) version 3.5.1. Department of Genome Sciences, University of Washington, Seattle, USA.

Hasegawa, T. (1988a). Actinokineospora: a new genus of the Actinomycetales. Actinomycetologica 2, 31-45.

Hasegawa, T. (1988b). Actinokineospora gen. nov. In Validation of the Publication of New Names and New Combinations Previously Effectively Published Outside the IJSB, List no. 27. Int J Syst Bacteriol 38, 449.

Hasegawa, T., Lechevalier, M. P. \& Lechevalier, H. A. (1978). A new genus of Actinomycetales: Actinosynnema gen. nov. Int J Syst Bacteriol 28, 304-310.

Henssen, A. (1957). Beiträge zur Morphologie und Systematik der thermophilen Actinomyceten. Arch Mikrobiol 26, 373-414 (in German).

Indananda, C., Matsumoto, A., Inahashi, Y., Takahashi, Y., Duangmal, K. \& Thamchaipenet, A. (2010). Actinophytocola oryzae gen. nov., sp. nov., isolated from the roots of Thai glutinous rice plants, a new member of the family Pseudonocardiaceae. Int J Syst Evol Microbiol 60, 1141-1146.

Jeon, Y.-S., Chung, H., Park, S., Hur, I., Lee, J.-H. \& Chun, J. (2005). jPHYDIT: a JAVA-based integrated environment for molecular phylogeny of ribosomal RNA sequences. Bioinformatics 21, 3171-3173.

Jiang, Y., Wiese, J., Tang, S. K., Xu, L. H., Imhoff, J. F. \& Jiang, C. L. (2008). Actinomycetospora chiangmaiensis gen. nov., sp. nov., a new member of the family Pseudonocardiaceae. Int J Syst Evol Microbiol 58, 408-413.

Kim, S. B. \& Goodfellow, M. (1999). Reclassification of Amycolatopsis rugosa Lechevalier et al. 1986 as Prauserella rugosa gen. nov., comb. nov. Int J Syst Bacteriol 49, 507-512.

Kimura, M. (1980). A simple method for estimating evolutionary rates of base substitutions through comparative studies of nucleotide sequences. J Mol Evol 16, 111-120.

Korn-Wendisch, F., Kempf, A., Grund, E., Kroppenstedt, R. M. \& Kutzner, H. J. (1989). Transfer of Faenia rectivirgula Kurup and Agre 1983 to the genus Saccharopolyspora Lacey and Goodfellow 1975, elevation of Saccharopolyspora hirsuta subsp. taberi Labeda 1987 to species level, and emended description of the genus Saccharopolyspora. Int J Syst Bacteriol 39, 430-441.

Korn-Wendisch, F., Rainey, F., Kroppenstedt, R. M., Kempf, A., Majazza, A., Kutzner, H. J. \& Stackebrandt, E. (1995). Thermocrispum gen. nov., a new genus of the order Actinomycetales, and description of Thermocrispum municipale sp. nov. and Thermocrispum agreste sp. nov. Int J Syst Bacteriol 45, 67-77.
Labeda, D. P. (2001). Crossiella gen. nov., a new genus related to Streptoalloteichus. Int J Syst Evol Microbiol 51, 1575-1579.

Labeda, D. P. \& Kroppenstedt, R. M. (2000). Phylogenetic analysis of Saccharothrix and related taxa: proposal for Actinosynnemataceae fam. nov. Int J Syst Evol Microbiol 50, 331-336.

Labeda, D. P. \& Kroppenstedt, R. M. (2006). Goodfellowia gen. nov., a new genus of the Pseudonocardineae related to Actinoalloteichus, containing Goodfellowia coeruleoviolacea gen. nov., comb. nov. Int J Syst Evol Microbiol 56, 1203-1207.

Labeda, D. P. \& Kroppenstedt, R. M. (2007). Proposal of Umezawaea gen. nov., a new genus of the Actinosynnemataceae related to Saccharothrix, and transfer of Saccharothrix tangerinus Kinoshita et al. 2000 as Umezawaea tangerina gen. nov., comb. nov. Int J Syst Evol Microbiol 57, 2758-2761.

Labeda, D. P. \& Kroppenstedt, R. M. (2008). Proposal for the new genus Allokutzneria gen. nov. within the suborder Pseudonocardineae and transfer of Kibdelosporangium albatum Tomita et al. 1993 as Allokutzneria albata comb. nov. Int J Syst Evol Microbiol 58, 14721475.

Labeda, D. P. \& Lechevalier, M. P. (1989). Amendment of the genus Saccharothrix Labeda et al. 1984 and descriptions of Saccharothrix espanaensis sp. nov., Saccharothrix cryophilis sp. nov., and Saccharothrix mutabilis comb. nov. Int J Syst Bacteriol 39, 420-423.

Labeda, D. P., Testa, R. T., Lechevalier, M. P. \& Lechevalier, H. A. (1984). Saccharothrix: a new genus of the Actinomycetales related to Nocardiopsis. Int J Syst Bacteriol 34, 426-431.

Labeda, D. P., Hatano, K., Kroppenstedt, R. M. \& Tamura, T. (2001). Revival of the genus Lentzea and proposal for Lechevalieria gen. nov. Int J Syst Evol Microbiol 51, 1045-1050.

Labeda, D. P., Kroppenstedt, R. M., Euzéby, J. P. \& Tindall, B. J. (2008). Proposal of Goodfellowiella gen. nov. to replace the illegitimate genus name Goodfellowia Labeda and Kroppenstedt 2006. Int J Syst Evol Microbiol 58, 1047-1048.

Labeda, D. P., Price, N. P., Tan, G. Y. A., Goodfellow, M. \& Klenk, H.-P. (2010). Emended description of the genus Actinokineospora Hasegawa 1988 and transfer of Amycolatopsis fastidiosa Henssen et al. 1987 as Actinokineospora fastidiosa comb. nov. Int J Syst Evol Microbiol 60, 1444-1449.

Lacey, J. \& Goodfellow, M. (1975). A novel actinomycete from sugarcane bagasse: Saccharopolyspora hirsuta gen. et sp. nov. J Gen Microbiol 88, 75-85.

Lechevalier, M. P., Prauser, H., Labeda, D. P. \& Ruan, J. S. (1986). Two new genera of nocardioform actinomycetes: Amycolata gen. nov. and Amycolatopsis gen. nov. Int J Syst Bacteriol 36, 29-37.

Lee, S. D. (2009). Amycolatopsis ultiminotia sp. nov., isolated from rhizosphere soil, and emended description of the genus Amycolatopsis. Int J Syst Evol Microbiol 59, 1401-1404.

Li, W. J., Xu, P., Tang, S. K., Xu, L. H., Kroppenstedt, R. M., Stackebrandt, E. \& Jiang, C. L. (2003). Prauserella halophila sp. nov. and Prauserella alba sp. nov., moderately halophilic actinomycetes from saline soil. Int J Syst Evol Microbiol 53, 1545-1549.

Ludwig, W., Strunk, O., Westram, R., Richter, L., Meier, H., Yadhukumar, Buchner, A., Lai, T., Steppi, S. \& other authors (2004). ARB: a software environment for sequence data. Nucleic Acids Res 32, 1363-1371.

Mao, J., Wang, J., Dai, H. Q., Zhang, Z. D., Tang, Q. Y., Ren, B., Yang, N., Goodfellow, M., Zhang, L. X. \& Liu, Z. H. (2011). Yuhushiella deserti gen. nov., sp. nov., a new member of the suborder Pseudonocardineae. Int J Syst Evol Microbiol 61, 621-630.

Nonomura, H. \& Ohara, Y. (1971). Distribution of actinomycetes in soil. X. New genus and species of monosporic actinomycetes in soil. J Ferment Technol 49, 895-903. 
Park, S. W., Park, S. T., Lee, J. E. \& Kim, Y. M. (2008). Pseudonocardia carboxydivorans sp. nov., a carbon monoxide-oxidizing actinomycete, and an emended description of the genus Pseudonocardia. Int J Syst Evol Microbiol 58, 2475-2478.

Saitou, N. \& Nei, M. (1987). The neighbor-joining method: a new method for reconstructing phylogenetic trees. Mol Biol Evol 4, 406-425.

Shearer, M. C., Colman, P. M., Ferrin, R. M., Nisbet, L. J. \& Nash, C. H., III (1986). New genus of the Actinomycetales: Kibdelosporangium aridum gen. nov., sp. nov. Int J Syst Bacteriol 36, 47-54.

Stackebrandt, E., Kroppenstedt, R. M., Jahnke, K. D., Kemmerling, C. \& Gürtler, H. (1994). Transfer of Streptosporangium viridogriseum (Okuda et al. 1966), Streptosporangium viridogriseum subsp. kofuense (Nonomura and Ohara 1969), and Streptosporangium albidum (Furumai et al. 1968) to Kutzneria gen. nov. as Kutzneria viridogrisea comb. nov., Kutzneria kofuensis comb. nov., and Kutzneria albida comb. nov., respectively, and emendation of the genus Streptosporangium. Int J Syst Bacteriol 44, 265-269.

Stackebrandt, E., Rainey, F. A. \& Ward-Rainey, N. L. (1997). Proposal for a new hierarchic classification system, Actinobacteria classis nov. Int J Syst Bacteriol 47, 479-491.

Stamatakis, A. P., Ludwig, T., Meier, H. \& Wolf, M. J. (2002). AxML: a fast program for sequential and parallel phylogenetic tree calculations based on the maximum likelihood method. Proc IEEE Comput Soc Bioinform Conf 1, 21-28.

Tamura, T., Zhiheng, L., Yamei, Z. \& Hatano, K. (2000). Actinoalloteichus cyanogriseus gen. nov., sp. nov. Int J Syst Evol Microbiol 50, 1435-1440.

Tamura, T., Ishida, Y., Otoguro, M., Hatano, K. \& Suzuki, K. (2008). Classification of 'Streptomyces tenebrarius' Higgins and Kastner as
Streptoalloteichus tenebrarius nom. rev., comb. nov., and emended description of the genus Streptoalloteichus. Int J Syst Evol Microbiol 58, 688-691.

Tang, S.-K., Wang, Y., Zhang, H., Lee, J.-C., Lou, K., Kim, C.-J. \& Li, W.-J. (2010). Haloechinothrix alba gen. nov., sp. nov., a halophilic filamentous actinomycete of the suborder Pseudonocardineae. Int J Syst Evol Microbiol 60, 2154-2158.

Tian, X. P., Zhi, X. Y., Qiu, Y. Q., Zhang, Y. Q., Tang, S. K., Xu, L. H., Zhang, S. \& Li, W.-J. (2009). Sciscionella marina gen. nov., sp. nov., a marine actinomycete isolated from a sediment in the northern South China Sea. Int J Syst Evol Microbiol 59, 222-228.

Tomita, K., Nakakita, Y., Hoshino, Y., Numata, K. \& Kawaguchi, H. (1987). New genus of the Actinomycetales: Streptoalloteichus hindustanus gen. nov., nom. rev.; sp. nov., nom. rev. Int J Syst Bacteriol 37, 211-213.

Yassin, A. F., Rainey, F. A., Brzezinka, H., Jahnke, K.-D., Weissbrodt, H., Budzikiewicz, H., Stackebrandt, E. \& Schaal, K. P. (1995). Lentzea gen. nov., a new genus of the order Actinomycetales. Int J Syst Bacteriol 45, 357-363.

Yuan, L.-J., Zhang, Y.-Q., Yu, L.-Y., Liu, H.-Y., Guan, Y., Lee, J.-C., Kim, C.-J. \& Zhang, Y.-Q. (2010). Alloactinosynnema album gen. nov., sp. nov., a member of the family Actinosynnemataceae isolated from soil. Int J Syst Evol Microbiol 60, 39-43.

Zhi, X. Y., Li, W.-J. \& Stackebrandt, E. (2009). An update of the structure and 16S rRNA gene sequence-based definition of higher ranks of the class Actinobacteria, with the proposal of two new suborders and four new families and emended descriptions of the existing higher taxa. Int J Syst Evol Microbiol 59, 589-608. 